10 Steer HW Surface morphology of the gastroduodenal mucosa in duodenal ukeration. Ge 1984;25:1203-10.

11 Warrea JR, Marshall B. Unidentified curved bacilli on gastric epithelium in active chronic gastritis. Lance 1983;i:1273-5.

12 Marshall BJ, Royce H, Annear DI, el al. Original isolation of campylobacter pyloridis from buman gastric mucosen. Microbios Laters 1984;25:83-8.

13 Allen A, Garner A. Mucus and bicarbonate secretion in the stomach and their possible role in mucosel procection. Guel 1980;21:249-62.

14 Hazell SL, Lee $\Lambda$. The adaption of motile strains of Campylobecter pyloridis to gastric mucus and their association with gastric epithetial intracelluhr spaces. In: Pearson AD, Skirrow MB, Lior H, Rowe B, eds. Cenpylablacter III: procentings of the thind intemational workshop on H, Rowe B, eds. Campylabacter III: proceediegs of the thind intemational wort

15 Goodwin CS, Armstrong JA. Will antibecterial chemothernpy be efficacious for gastritis and peptic ulcer? I Antinicreb Chemocher 1986;17:1-4.

16 O'Connor HJ, Wyatt JI, Dixon MF, Axon ATR. Campylobacter like organisms and reflux gastritis. J Clin Pathol 1986;39:531-4.

17 O'Coanor HJ, Axon ATR, Dixon MF. Campylobacter-like onganisms unusual in type A (pernicious anaemia) gastritis. Lance 1984;ii:1091.

18 Marshall BJ, Armstrong JA, McGechie DB, Glancy RJ. Attempt to futfil Koch's postulates for pyloric campylobecter. Med J Aus 1985;142:436-9.

19 Ramsay EJ, Carey KV, Peterson WL, et al. Epidemic gastritis with hypochlorhydria. Gastroenterdosy 1979;76:1449-57.

20 Kaldor J. Tee $W$, McCarthy P, Watson J, Dwyer B. Immune response to Campylobecter pyloridis in patients with peptic ulceration. Lancet 1985; 921.

21 Rathbone BJ, Wyatt JI, Worstey BW, et al. Systemic and local antibody responses to gastric Campylobecter pyloridis in non-uker dyspepsia. Gut 1986;27:642-7.

22 Wyatt JI, Rathbone BJ, Heatley RV. Local immune response to gastric campylobacter in nonukeer dyspepsia. I Clin Path (in press).

23 Strickland RG. Chronic gastritis. In: Bouchier IAD, Allan RN, Hodgson HJF, Keighley MRB ods. Textbook of gastroenterology. London: Baillière Tindall, 1984:113-24.

24 Hazell SL, Loe A. Campylobacter pyloridis, urease, hydrogen ion back diffusion, and gastric ukers. Lancet 1986; ii: $15-7$.

25 Diaz MQ, Escobar AS. Metronidazole versus cimetidine in treatment of gastroduodenal ulcer. Lancet 1096;i:907.

26 McLean AJ, Harrison PM, Ioannides-Demos LL, Byrne AJ, McCarthy P, Dudley FJ. Microbes, peptic ulcer, and retapse rates with different drugs. Lancet 1984;ii:525-6.

\section{Isolating the gene for Duchenne muscular dystrophy}

Despite much work on muscle and other tissues we still have no clear indication of what the primary defect is in Duchenne muscular dystrophy, and this makes rational approaches to treatment and prevention difficult. The new recombinant DNA techniques allow identification of a gene without requiring information on what that gene does, and these have allowed research to break out of what might have been stagnation and given five years of remarkable progress.

The first clue came from the observation of a rarity: the occurrence of several cases of Duchenne muscular dystrophy in girls carrying a chromosome rearrangement affecting the $\mathrm{X}$ chromosome. ${ }^{1}$ Initially these were thought likely to be incidental changes, but as other cases were reported it became clear that the breakpoint on the $\mathrm{X}$ chromosome was at the same site in each-the central area of the short arm of the $\mathrm{X}$ known as band $\mathrm{p} 21 .{ }^{2}$ Over 15 such cases are now known, and this constancy has remained, leaving no doubt that the break is at the site of the Duchenne muscular dystrophy gene.

Soon after the recognition of these cases it became possible to produce markers for the Duchenne muscular dystrophy gene that could be studied in families. ${ }^{3}$ These DNA markers -inherited variations in DNA sequence recognised by producing fragments of different size and known as restriction fragment length polymorphisms-could be localised to the $\mathrm{X}$ chromosome by physical methods and then tested in families with the disorder to show whether the markers had been inherited in parallel with the disease. The year 1982 saw the first such markers linked to Duchenne muscular dystrophy, ${ }^{4}$ and in 1983 a second marker was placed on the opposite side of the gene. ${ }^{5}$ Both firmly placed the Duchenne muscular dystrophy gene at p21, the same site as that suspected from the girls with chromosome defect.
Furthermore, the gene for the milder "Becker" form of muscular dystrophy (previously thought to be quite separate) proved to be at the same site. ${ }^{6}$

These markers opened the way to prediction for the Duchenne muscular dystrophy gene, since by typing the markers in a family - particularly when both markers could be used together-the presence of the Duchenne muscular dystrophy gene itself could be inferred.' The search was now on for closer and more informative markers, and within a year at least seven had been detected, greatly increasing the proportion of families who could be helped by carrier detection, ${ }^{8}$ and allowing also the possibility of early prenatal prediction by chorion biopsy in occasional cases.'

At this stage, around mid-1985, the suspicion became strong that the Duchenne muscular dystrophy gene was not a conventional one. Despite some of the DNA markers being physically close, all showed relatively frequent recombination between marker and disease, ${ }^{10}$ suggesting that the gene might be in an unstable site with much mutation and rearrangement. Recent developments have shown that this is indeed the case, thanks to two remarkable pieces of research that have brought us to the threshold of the gene itself.

The first of these, by Lou Kunkel and colleagues in Boston, was based on the study of a boy who had both Duchenne muscular dystrophy and a visible chromosome deletion." "2 When DNA sequences isolated from the deleted region were tested against others from patients with "ordinary" Duchenne muscular dystrophy it became clear that some of them were missing the Duchenne muscular dystrophy gene, even though they were chromosomally normal. About $7 \%$ of cases are now known to be associated with gene deletions-the first step in molecular analysis of the defect. At the same time Worton and colleagues in Toronto were able to isolate and clone the DNA from the breakpoint on the $\mathrm{X}$ chromosome of one of the girls with muscular dystrophy and a chromosome translocation. ${ }^{13}$ As predicted this DNA sequence proved to be integrally related to the Duchenne muscular dystrophy gene, showing deletions in most of the cases which were missing Kunkel's "pERT" probe.

These two experiments, reaching the same endpoint from different approaches, might have been expected to have solved the problem and allowed the gene itself to be fully analysed and its product identified. This has not happened, however, and we seem to be dealing with a very large region of DNA (perhaps several million base pairs) in which a change at different points may result in Duchenne or Becker muscular dystrophy. So far there is no sign of a single functional gene in this region.

How does this answer the questions for clinicians looking after families with Duchenne and Becker muscular dystrophy? The first group for whom there has been a real advance is those in whom a gene deletion is present. Here one can offer carriers an accurate and specific first trimester prenatal diagnosis, so it is most important that such boys and their relatives are carefully tested. For the majority not showing a deletion there remains a finite error of around $5 \%$ even using the new markers integrally related to the gene. Nevertheless, most carriers may now be predicted accurately by combining DNA analysis with the older approach of creatine kinase testing. If prenatal diagnosis is undertaken the family must realise that we still do not have a totally accurate prediction, though a $95 \%$ accuracy rate will be acceptable to some. For all families the rapid progress of the past five years is a cause for real optimism, since we are now 
close to understanding the defect in molecular terms and will soon be able to return to recognise a specific gene product. This will then provide the foundation for attempts at therapeutic intervention, something which may still be distant, but which will at least have a well founded scientific basis.

Peter S HaRper

Professor of Medical Genetics,

University of Wales College of Medicine, Cardiff CF4 4XN

1 Lindenbaum RH, Clarke G, Patel C, Moncrieff C, Hughes JT. Muscular dystrophy in an X;1 translocation female suggests that Duchenne locus is on $\mathrm{X}$ chromosome short arm. I Med Genet 1979;16:389-92.

2 Jacobs PA, Hunt PA, Mayer M, Bart RD. Duchenne muscular dystrophy (DMD) in a female with an $\mathrm{X}$ /authosome translocation: Further evidence that the DMD locus is at Xp21. Am $\mathrm{f} \mathrm{Hum}$ Genet 1981;33:513-8.

3 Davies KE, Young BD, Elles RG, Hill ME, Williamson R. Cloning of a representative genomic library of the human X chromosome after sorting by flow cytometry. Nature 1981;293:374-6.

4 Murray JM, Davies KE, Harper PS, Meredith L, Mueller CR, Williamson R. Linkage relationship of a cloned DNA sequence of the short arm of the X-chromosome to Duchenne muscular dystrophy. Nature 1982;300:69-71.

5 Davies KE, Pearson PL, Harper PS, et al. Linkage analysis of two cloned DNA sequences flanking the Duchenne muscular dystrophy locus on the short arm of the human X-chromosome. Nucleic Acids Res 1983;11:2303-12.

6 Kingston HM, Sarfarazi M, Thomas NST, Harper PS. Localisation of the Becker muscular dystrophy gene on the short arm of the X-chromosome by linkage to cloned DNA sequences. Hum Genet 1984;67:6-17.

7 Harper PS, O'Brien T, Murray JM, Davies KE, Pearson P, Williamson R. The use of linked DNA polymorphisms for genotype prediction in families with Duchenne muscular dystrophy. $\mathcal{J}$ Med Genet 1983;20:252-254.

8 Williams H, Sarfarazi M, Brown CS, Thomas NST, Harper PS. The use of flanking markers in prediction for Duchenne muscular dystrophy. Arch Dis Child 1986;61:218-22.

9 Bakker E, Goor N, Wrogemann K, et al. Prenatal diagnosis and carrier detection of Duchenne muscular dystrophy with closely linked RFLPs. Lancet 1985;i:655-8.

10 Brown CS, Thomas NST, Sarfarazi M, et al. Genetic linkage relationships of seven DNA probes with Duchenne and Becker muscular dystrophy. Hum Genet 1985;71:62-74.

11 Kunkel LM, Monaco AP, Middlesworth W, Ochs HD, Latt SA. Specific cloning of DNMA fragments absent from the DNA of a male patient with and $\mathrm{X}$ chromosome deletion. Proc Natl Acad Sci USA 1985;82:4778-82.

12 Monaco AP, Bertelson CJ, Middlesworth W, et al. Detection of deletions spanning the Duchenne muscular dystrophy locus using a tightly linked DNA segment. Nature 1985;316:842-5.

13 Ray PN, Belfall B, Duff C, et al. Cloning of the breakpoint of an X;21 translocation assaciation with Duchenne muscular dystrophy. Nature 1985;318:672-5.

\section{Drunken driving among the young}

The fact that the life expectancy of those aged 15-24 is less than it was 20 years ago in some industrialised countries should give food for thought to the architects of the campaign for "health for all by the year 2000," but public health authorities do not seem much concerned. The cause of this fall is motor vehicle accidents, the prevention of which is not normally regarded as a job for health departments. In many countries, including England and Wales, such accidents now account for more than half of all male deaths among those aged 15-19,' and the most important cause of these accidents is alcohol. ${ }^{2}$

It was for this reason that the International Driver Behaviour Research Association decided that its contribution towards the European Road Safety Year should be to assemble a group of international experts to discuss impairment of young drivers by alcohol and other drugs. The number of teenagers driving motor vehicles has increased; their consumption of alcohol has increased, and so have their convictions for both public drunkenness and driving while impaired by alcohol. There are important differences in lifestyles, social environment, and attitudes between those teenagers who drive while impaired by alcohol and those who do not-and each country needs to be aware of these differences before effective countermeasures can be intro- duced. The main reason for failure to contain these accidents is that they have too often been dealt with in isolation. Much needed research has not been done because it infringes the rigid demarcation lines between government departments responsible for transport, health, education, and law enforcement.

Meanwhile, some measures have worked-for example, increasing the legal drinking age. The number of teenage motor vehicle accidents is inversely related to the legal drinking age, and results from several countries have shown that lowering the age increases such accidents and that increasing it has the converse effect. This was particularly noticeable in the United States, where several states reduced their legal drinking age during the 1970s. The federal government has now given state legislatures until the end of October to restore their legal age to "the respectable age" of 21 . The five states that have not complied are expected to fall into line soon. Any attempt to introduce such a measure in Britain, where the legal age of 18 is honoured in the breach, would provoke cries of infringement of personal liberty. The same cries greeted attempts to introduce the compulsory wearing of seat belts-which are now worn without protest by $96 \%$ of drivers and front seat passengers.

Younger drivers are more likely than experienced drivers to have accidents at lower blood alcohol concentrations, and several countries have introduced a lower statutory limit for novice drivers and - as expected ${ }^{3}$ - reduced their accident rates. This policy has been particularly effective when combined with "random" breath tests. Perhaps the most important finding was that such measures were not effective in those countries that had not introduced them as part of an integrated and comprehensive programme of countermeasures including school education, public education, and synchronised media presentations aimed not only at young drivers but also at parents, peer groups, and others who influence the attitudes and behaviour of teenagers. In this connection the targeting of alcohol adverts at teenagers was thought by the conference to be particularly pernicious - and it has increased recently in several countries.

The conference called strongly for countries to introduce urgently integrated and comprehensive approaches to the problem. But this call will go unheeded in some of the countries with the most serious problems-the government departments for both health and transport from France, West Germany, and Italy were not represented. Perhaps the final word should rest with the internationally respected director of a North American traffic injury research institute who applied to his country's ministry of health for a modest grant to study the subject. His request was refused because "it is not a public health problem." Unfortunately, although not surprisingly, no sponsor has yet been found to publish the proceedings of the conference, which include the best advice available on improving the life expectancy of our teenagers.

JOHN HAVARD

Secretary,

BMA

BMA House,

London WC1H 9JP

1 Havard JDJ. Mortality from motor vehicle accidents in the 15-24 year age group. World Health Stat $Q$ 1979;32:225-41.

2 Mayhew MA, Simpson HM. Alcohol, age, and risk of road accident involvement. In: Kaye S, Meier GW, eds. Alcohol, drugs and traffic safery. Proceedings of the ninth international conference, San fuan, Puerto Rico, 1983. Washington DC: US Department of Transport National Highway Traffic Safety Administration, 1985:937-47.

3 Smith DI. Effect of low proscribed blood alcohol levels (BALs) on traffic accidents among newlylicensed drivers. Med Sci Law 1986-26:144-8. 